AGH DRILLING, OIL, GAS • Vol. 33 • No. 1 • 2016

http://dx.doi.org/10.7494/drill.2016.33.1.23

Jan Macuda*, Małgorzata Macuda**

\title{
DRILLING LARGE DIAMETER INTAKE WELLS WITH CUTTER BITS \\ IN LOOSE AND WEAKLY CONSOLIDATED ROCKS***
}

\section{INTRODUCTION}

Most of the useful aquifers occur in the Quaternary and Tertiary horizons, which are deposited at a depth of tens to hundreds of meters. Owing to the need of providing large quantities of water for municipal and industrial purposes, the aquifers are more and more frequently opened with large diameter wells of various designs. Such wells are mostly drilled with the rotary method with reverse mud circulation with the use of various bits. The Quaternary and Tertiary strata abound in loose and weakly consolidated rocks therefore cutter bits are predominantly used. They allow for high rates of drilling and shorter time of drilling of the well. This significantly influences the negative influence of drilling mud on the near screen zone of the aquifer and better hydraulic properties of the well.

Drillability tests bits were performed with cutter for providing high rates of drilling of large diameter intake wells in loose and weakly consolidated rocks. The obtained results will be used for designing optimum mechanical parameters of drilling of large diameter wells.

\section{DESIGNS OF LARGE DIAMETER WELLS PRODUCING GROUNDWATER FROM LOOSE FORMATIONS}

Aquifers deposited at small depths and having good filtration parameters should be opened with large diameter wells. Large diameter screens with coarse gravel pack can be used for such wells. In this solution the high-rate pump aggregates can be installed.

* AGH University of Science and Technology, Faculty of Drilling, Oil and Gas, Krakow, Poland

** Poznań University of Economics and Business, al. Niepodległości 10, 61-875 Poznań

*** Work performed within the statutory research program of AGH UST No. 11.11.190.555 
The choice of the intake well design always depends on the geologic and hydrogeologic conditions, required yield and depth of groundwater level. The casing of large diameter intake wells consists of one or more casing columns and the screen column. The most frequently applied design variants of large diameter wells drilled to ca. $300 \mathrm{~m}$ are presented in Figure 1, and their designs in Table 1. Variants a) and b) are used when drilling shallow wells, intaking one water-bearing horizon. Variants c) and d) are most commonly applied when two aquifers or one water-bearing horizon appear in permeable strata interbedded with impermeable layers $[1,9]$.

a)

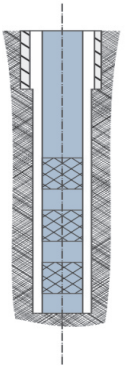

b)

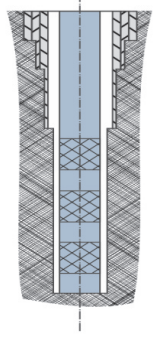

c)

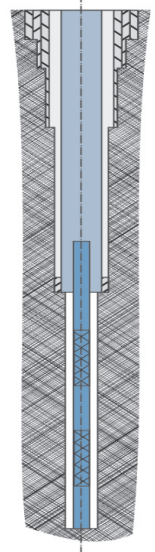

d)

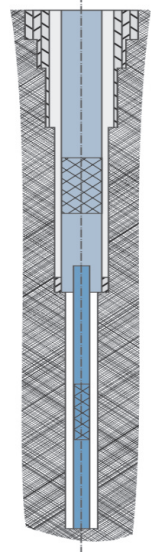

Fig. 1. Casing of large diameter intake wells drilled with rotary method

Table 1

Design of large diameter intake wells drilled with rotary method to a depth of $300 \mathrm{~m}$

\begin{tabular}{|c|c|c|c|}
\hline Design variant & $\begin{array}{c}\text { Bit diameter } \\
{[\mathrm{m}]}\end{array}$ & $\begin{array}{c}\text { Outer diameter of casing } \\
\text { and screen }[\mathrm{m}]\end{array}$ & $\begin{array}{c}\text { Clearing } \\
{[\mathrm{m}]}\end{array}$ \\
\hline $\mathbf{a}$ & 0.96 & 0.920 & 0.02 \\
& 0.76 & 0.508 & 0.12 \\
\hline $\mathbf{b}$ & 1.16 & 1.016 & 0.07 \\
& 0.96 & 0.920 & 0.02 \\
& 0.86 & 0.620 & 0.12 \\
\hline $\mathbf{c}$ & 1.36 & 1.220 & 0.07 \\
& 1.16 & 1.016 & 0.07 \\
& 0.96 & 0.711 & 0.12 \\
$\mathbf{d}$ & 0.67 & 0.508 & 0.08 \\
\hline & 1.36 & 1.220 & 0.07 \\
& 1.16 & 0.920 & 0.12 \\
& 0.86 & 0.620 & 0.12 \\
\hline
\end{tabular}




\section{MATHEMATICAL MODELS OF DRILLING WITH CUTTER BITS}

The operation of cutter tools is most frequently described with qualitative-quantitative models, taking into account some coefficients relating to the efficiency of machining and wearing of the bit $[5,10]$. If these parameters are defined correctly for a given type of bit and of the drilled rock, the theoretical model can be properly adjusted to the actual character of work of the bit. The determined coefficients and model of drilling create bases for the selection of optimum parameters of drilling. In this way the drilling rate can be increased, and so the efficiency of performance increased $[2,6]$.

When drilling large diameter wells at small depth in loose and weakly consolidated rocks, these models are assumed with constant drilling rate, for which the wearing of the cutter bits is not taken into account. Such models are usually described with the equations $[10,16]$ :

$$
\begin{gathered}
V=\left(V_{0}\right)^{-b t}[\mathrm{~m} / \mathrm{s}] \\
V=V_{0}\left(e^{-a t}\right)[\mathrm{m} / \mathrm{s}] \\
V=\frac{V_{0}}{1+m t}[\mathrm{~m} / \mathrm{s}]
\end{gathered}
$$

where:

$$
\begin{aligned}
V & - \text { momentary rate of drilling }[\mathrm{m} / \mathrm{s}], \\
V_{0} & - \text { initial rate of drilling }[\mathrm{m} / \mathrm{s}], \\
b, a, m & - \text { coefficients of drilling rate decrease }[-], \\
t & - \text { time of drilling }[\mathrm{s}] .
\end{aligned}
$$

Short drilling cycles are usually applied when drilling shallow intake wells in loose and weakly consolidated rocks. In this situation we can assume the influence of cutter bit blades on drilling rate and the above models can be reduced to the form $V=V_{0}$. The initial drilling rate $V_{0}$ is most importantly influenced by axial weight on bit and the rotational velocity, properties of the drilled rock and the bit/rock interaction. For this reason the initial drilling rate is described with the formula $[6,8]$ :

$$
V_{0}=Z \cdot P^{a} \cdot n^{b}
$$

where:

$$
\begin{aligned}
& Z-\text { drillability coefficient }[-], \\
& P-\text { axial weight on bit }[\mathrm{N}], \\
& n-\text { rotational velocity of bit }\left[\mathrm{s}^{-1}\right] \\
& a-\text { impact of axial weight on bit on mechanical rate of drilling }[-], \\
& b-\text { impact of rotational rate of bit on mechanical rate of drilling }[-] .
\end{aligned}
$$


Drillability coefficient $Z$ always has a positive value and the higher is its value, the more easily the rock can be drilled and the higher rate of drilling will be obtained. Depending on the properties of the drilled rocks, exponent $a$ varies from 0.6 to 2.3 , and $b$ from 0.1 to $1.0[6,11]$.

The instantaneous mechanical rate of drilling is also significantly influenced by hydraulic parameters of washing wellbore bottom $[9,15]$. With the increase of mud density, dispersion degree and kinematic viscosity, the drilling rate decreases. On the other hand the rate of drilling increases with the growing filtration of mud.

\section{DRILLABILITY TESTS WITH THE USE OF CUTTER BITS}

The drillability of loose and weakly consolidated rocks with cutter bits was tested for the sake of increasing the rate of drilling of large diameter wells in industrial conditions. The tests were carried out in line with principles presented in $[6,9,11]$. Two cutter bits of diameter $0.86 \mathrm{~m}$ and $0.67 \mathrm{~m}$ were used for performing the longest sections of the well for screen columns.

Two macroscopically homogeneous layers, i.e. having similar drillability for a given type of bit, were selected for drillability tests in a geological profile of a well, based on literature $[7,14]$ :

A - sands, gravels,

B - clays, silts, loess, mudstone.

Drillability tests made for cutter bits of diameter $0.86 \mathrm{~m}$ and 0.67 were conducted for the following drilling parameters:

- axial weight on bit $1.96-2.45 \cdot 10^{4}[\mathrm{~N}]$,

- rotational velocity of bit $0.75-1.66\left[\mathrm{~s}^{-1}\right]$,

- mud flow rate $0.08\left[\mathrm{~m}^{3} / \mathrm{s}\right]$,

- flow rate of mud inside the drill string $4.3[\mathrm{~m} / \mathrm{s}]$.

Depending on the designed thickness of drilled rock, the determined measurement sections were 0.5 and $1.0 \mathrm{~m}$ long. Each measurement section was drilled at a constant rotational velocity and a constant axial weight on bit with Prakla RB 50 rig.

\section{RESULTS AND DISCUSSION}

Various regression models were analyzed for the sake of establishing a relation between the mechanical rate of drilling and axial weight on bit and rotational velocity of bit in macroscopically distinguished layers $\mathrm{A}$ and $\mathrm{B}[3,4,12]$. The best results were 
obtained for the exponent model illustrating the influence of axial weight on bit and rotational velocity of bit on the drilling rate. The regression coefficients and statistical parameters prove a good fitting of the model to the measurement data, as presented in Tables 2 to 5 .

The average drilling rate for cutter bits is described with the formula:

$$
V_{a v}=Z \cdot P^{a} \cdot n^{b}
$$

For the sake of analysing the exponent model illustrating the influence of axial weight on bit and rotational velocity of bit, equation (5) was logarithmized by sides and transformed to a linear form:

$$
\ln V_{a v}=\ln Z+a \cdot \ln P+b \cdot \ln n
$$

Regression coefficients for model (6) and their statistical significance were calculated with the use of program STATISTICA - multiple regression module [13].

Apart from coefficients of equations for average mechanical rate of drilling with cutter bits in particular layers, Tables 2 to 5 also give parameters which verify the statistical correctness of the model:

- population $m$,

- multiple correlation coefficient $R$,

- $t$ Student value for particular regression coefficients,

- $F$ Snedecor test value $F$,

- drillability coefficient $Z$,

- residual error $B$,

- significance level $\alpha=0.05$.

Table 2

Parameters of equation for average mechanical rate of drilling with cutter bit of $0.86 \mathrm{~m}$ diameter in A-type layers

\begin{tabular}{|c|c|c|c|}
\hline $\begin{array}{c}\text { Dependent } \\
\text { parameter }\end{array}$ & $\begin{array}{c}\text { Regression } \\
\text { coefficient }\end{array}$ & $\begin{array}{c}\text { Standard error } \\
\text { coefficient }\end{array}$ & $\begin{array}{c}\text { Student's } \\
t \text {-test value }\end{array}$ \\
\hline$a$ & 0.801426 & 0.034533 & 23.2079 \\
\hline$b$ & 0.75993 & 0.034932 & 21.7547 \\
\hline Number of measurements $m=56$ & $\begin{array}{l}R=0.973 \\
R_{k}=0.374 \\
t_{k}=2.008\end{array}$ & $\begin{array}{l}F=497.400 \\
F_{k}=3.17 \\
\text { Free expression } Z=1.0841192710^{-7}\end{array}$ & $B=4.48 \%$ \\
\hline
\end{tabular}


Table 3

Parameters of equation for average mechanical rate of drilling with cutter bit of $0.86 \mathrm{~m}$ diameter in B-type layers

\begin{tabular}{|c|c|c|c|}
\hline $\begin{array}{c}\text { Dependent } \\
\text { parameter }\end{array}$ & $\begin{array}{c}\text { Regression } \\
\text { coefficient }\end{array}$ & $\begin{array}{c}\text { Standard error } \\
\text { coefficient }\end{array}$ & $\begin{array}{c}\text { Student's } \\
t \text {-test value }\end{array}$ \\
\hline$a$ & 0.915853 & 0.047734 & 19.1866 \\
\hline$b$ & 0.639158 & 0.051225 & 12.4774 \\
\hline Number of measurements $m=52$ & $\begin{array}{l}R=0.952 \\
R_{k}=0.388 \\
t_{k}=2.012\end{array}$ & $\begin{array}{l}F=251.967 \\
F_{k}=3.19 \\
\alpha=0.05\end{array}$ & $B=6.29 \%$ \\
\hline
\end{tabular}

Table 4

Parameters of equation for average mechanical rate of drilling with cutter bit of $0.67 \mathrm{~m}$ diameter in A-type layers

\begin{tabular}{|c|c|c|c|}
\hline $\begin{array}{c}\text { Dependent } \\
\text { parameter }\end{array}$ & $\begin{array}{c}\text { Regression } \\
\text { coefficient }\end{array}$ & $\begin{array}{c}\text { Standard error } \\
\text { coefficient }\end{array}$ & $\begin{array}{c}\text { Student's } \\
t \text {-test value }\end{array}$ \\
\hline$a$ & 0.978606 & 0.02794 & 35.0251 \\
\hline$b$ & 0.672183 & 0.021015 & 31.9855 \\
\hline Number of measurements $m=46$ & $\begin{array}{l}R=0.989 \\
R_{k}=0.409 \\
t_{k}=2.018\end{array}$ & $\begin{array}{l}F=1090.54 \\
F_{k}=3.121 \\
\alpha=0.05\end{array}$ & $B=3.03 \%$ \\
\hline
\end{tabular}

Table 5

Parameters of equation for average mechanical rate of drilling with cutter bit of $0.67 \mathrm{~m}$ diameter in B-type layers

\begin{tabular}{|c|c|c|c|}
\hline $\begin{array}{c}\text { Dependent } \\
\text { parameter }\end{array}$ & $\begin{array}{c}\text { Regression } \\
\text { coefficient }\end{array}$ & $\begin{array}{c}\text { Standard error } \\
\text { coefficient }\end{array}$ & $\begin{array}{c}\text { Student's } \\
t \text {-test value }\end{array}$ \\
\hline$a$ & 1.36043 & 0.050065 & 27.1732 \\
\hline$b$ & 0.587293 & 0.04222 & 14.6013 \\
\hline Number of measurements $m=56$ & $\begin{array}{l}R=0.976 \\
R_{k}=0.419 \\
t_{k}=2.021\end{array}$ & $\begin{array}{l}F=424.548 \\
F_{k}=3.23 \\
\alpha=0.05\end{array}$ & $B=4.85 \%$ \\
\hline
\end{tabular}


Industrial tests were performed with the use of the average rate of drilling model to efficiently evaluate the efficiency of drilling large diameter intake wells drilled in loose and weakly consolidated rock with cutter bits of 0.66 and $0.67 \mathrm{~m}$ diameter. While drilling three wells with Prakla RB 50 rig, the following technological parameters were used, depending on the type of drilled rocks:

- outer diameter of drill string

$0.194 \mathrm{~m}$,

- axial weight on bit

$1.96-2.94 \cdot 10^{4} \mathrm{~N}$

- rotational velocity of bit

$0.75-1.66 \mathrm{~s}^{-1}$,

- mud flow rate

- low rate of mud inside drill string

$0.166 \mathrm{~m}^{3} / \mathrm{s}$,

$3.8 \mathrm{~m} / \mathrm{s}$.

The obtained values of average rate of drilling with cutter bits during industrial tests ranged between $6.91 \cdot 10^{-4}$ to $3.68 \cdot 10^{-3} \mathrm{~m} / \mathrm{s}$ and were higher than the obtained so far, i.e. 159.11 to $243.68 \%$.

\section{CONCLUSIONS}

1. The use of the presented model of average rate of drilling for cutter bits of diameter 0.86 and $0.67 \mathrm{~m}$ brought about considerably higher efficiency of drilling of large diameter intake wells in loose and weakly consolidated rocks.

2. The optimum mechanical parameters of drilling of large diameter wells should be selected in view of limitations imposed by the axial weight on bit and rotational velocity of bit.

3. When drilling large diameter wells with cutter bits attention should be paid to additional limitations imposed by the technological characteristic of the rig and the applied mud column.

\section{REFERENCES}

[1] AAdnøy B. S.: Modern wells and design. A.A. Balkema, Rotterdam1996.

[2] Besson A., Toutain P., Meany N.: Improved BHAs, bits optimize drilling performance. Drilling Contractors, vol. 49, No. 1,1993.

[3] Cobb G.W.: Introduction to Design and Analysis of Experiments. Springer, New York 1998.

[4] Dobosz M.: Wspomagana komputerowo statystyczna analiza wyników badań. EXIT, Warszawa 2001.

[5] Gonet A.: Calculation of optimum time of drilling the hole with cutter bit. Archiwum Górnictwa, vol. 37, No. 3, 1992.

[6] Gonet A.: Optymalizacja mechanicznych parametrów technologii wiercenia otworów cutter bits. Przegląd Górniczy, No. 5, 1995. 
[7] Kidybiński A.: Podstawy geotechniki kopalnianej. Wydawnictwo Śląsk, Katowice 1982.

[8] Macuda J.: Analiza technicznych wskaźników wiercenia wielkośrednicowych otworów odwadniajacych na złożu KWB Bełchatów. Zeszyty Naukowe AGH, Górnictwo, vol. 19. No. 2, 1995, pp. 121-129.

[9] Macuda J.: Analysis of Efficiency of Drilling of Large-diameter Wells with a Profiled Wing Bit. Archives of Mining Sciences, vol. 57, No. 2, 2012.

[10] Miska S.: Identyfikacja procesu wiercenia narzędziami skrawającymi. Archiwum Górnictwa, vol. 2, No. 3, 1975.

[11] Perry P.B., Curry D.A., Kerridge J.D., Lawton J.: A Case Based Knowledge Repository for Drilling Optimization. IADC/SPE Asia Pacific Drilling Technology Conference and Exhibition, 13-15 September, Kuala Lumpur, Malaysia, 2004.

[12] Sobczyk M.: Statystyka matematyczna. Wyd. C.H. Beck, 2010.

[13] Stanisz A.: Przystępny kurs statystyki z zastosowaniem STATISTICA PL na przykładach z medycyny. Wyd. StatSoft Polska, Kraków 2007.

[14] Wiłun Z.: Zarys geotechniki. Wydawnictwo WKiÆ, Warszawa 2003.

[15] Wiśniowski R., Stęperski P.: Wpływ parametrów reologicznych modelu HerschelaBulkleya na wynoszenie zwiercin. Wiertnictwo Nafta Gaz, vol. 25, No. 2, 2008.

[16] Wojnar K., Władislawlew S.W.: Wiertnictwo. Wydawnictwo Geologiczne, Warszawa 1976 